\title{
Attenuation of the effects of $d$-amphetamine on interval timing behavior by central 5-hydroxytryptamine depletion
}

\author{
S. Body $\cdot$ T. H. C. Cheung $\cdot$ C. L. Hampson • \\ F. S. den Boon • G. Bezzina $\cdot$ K. C. F. Fone • \\ C. M. Bradshaw $\cdot$ E. Szabadi
}

Received: 24 April 2008 / Accepted: 28 October 2008/Published online: 19 November 2008

(C) The Author(s) 2008. This article is published with open access at Springerlink.com

\begin{abstract}
Rationale Interval timing in the free-operant psychophysical procedure is sensitive to the monoamine-releasing agent $d$ amphetamine, the $\mathrm{D}_{2}$-like dopamine receptor agonist quinpirole, and the $\mathrm{D}_{1}$-like agonist 6-chloro-2,3,4,5-tetrahydro-1-phenyl-1H-3-benzepine (SKF-81297). The effect of $d$-amphetamine can be antagonized by selective $\mathrm{D}_{1}$-like and $5-\mathrm{HT}_{2 \mathrm{~A}}$ receptor antagonists. It is not known whether $d$-amphetamine's effect requires an intact 5-hydroxytryptamine (5-HT) pathway.

Objective The objective of this study was to examine the effects of $d$-amphetamine, quinpirole, and SKF-81297 on timing in intact rats and rats whose 5-hydroxytryptaminergic (5-HTergic) pathways had been ablated.

Materials and methods Rats were trained under the freeoperant psychophysical procedure to press levers A and B in 50-s trials in which reinforcement was provided intermittently for responding on $\mathrm{A}$ in the first half, and $\mathrm{B}$ in the second half of the trial. Percent responding on $\mathrm{B}(\%$ B) was recorded in successive 5-s epochs of the trials; logistic functions were fitted to the data for derivation of timing indices $\left(T_{50}\right.$, time corresponding to $\% \mathrm{~B}=50 \%$; Weber fraction). The effects of $d$-amphetamine $(0.4 \mathrm{mg}$ $\mathrm{kg}^{-1}$ i.p.), quinpirole (0.08 $\mathrm{mg} \mathrm{kg}^{-1}$ i.p.), and SKF-81297
\end{abstract}

\footnotetext{
S. Body $(\bowtie) \cdot$ T. H. C. Cheung • C. L. Hampson •

F. S. den Boon · G. Bezzina - C. M. Bradshaw - E. Szabadi

Psychopharmacology Section, Division of Psychiatry, Medical

School, Queen's Medical Centre, University of Nottingham,

Room B109,

Nottingham NG7 2UH, UK

e-mail: stephanie.body@nottingham.ac.uk

K. C. F. Fone

School of Biomedical Sciences, University of Nottingham,

Nottingham, UK
}

$\left(0.4 \mathrm{mg} \mathrm{kg}^{-1}\right.$ s.c.) were compared between intact rats and rats whose 5 -HTergic pathways had been destroyed by intra-raphe injection of 5,7-dihydroxytryptamine.

Results Quinpirole and SKF-81297 reduced $T_{50}$ in both groups; $d$-amphetamine reduced $T_{50}$ only in the shamlesioned group. The lesion reduced 5 -HT levels by $80 \%$; catecholamine levels were not affected.

Conclusions $d$-Amphetamine's effect on performance in the free-operant psychophysical procedure requires an intact 5HTergic system. 5-HT, possibly acting at $5-\mathrm{HT}_{2 \mathrm{~A}}$ receptors, may play a 'permissive' role in dopamine release.

Keywords Timing $\cdot$ Free-operant psychophysical procedure $\cdot \mathrm{D}_{1}$-like dopamine receptors $\cdot \mathrm{D}_{2}$-like dopamine receptors $\cdot 5$-HTergic pathways $\cdot 5,7$-dihydroxytryptamine . $d$-Amphetamine $\cdot$ SKF-81297 $\cdot$ Quinpirole

\section{Introduction}

Interval timing behavior in animals can be divided into two broad categories - temporal discrimination, where an animal learns to emit different responses depending on the duration of an external stimulus (e.g., a light or tone), and temporal differentiation, where the animal's behavior comes under the control of time during an ongoing interval (Killeen and Fetterman 1988; Killeen et al. 1997). This paper is concerned with the psychopharmacology of temporal differentiation.

Temporal differentiation is revealed by immediate timing schedules, an example of which is the free-operant psychophysical procedure (Stubbs 1976, 1980), in which reinforcement is provided intermittently for responding on two operanda, $\mathrm{A}$ and $\mathrm{B}$; responding on $\mathrm{A}$ is reinforced in the first half and responding on $\mathrm{B}$ in the second half of each 
trial. Temporal differentiation performance is assessed quantitatively from the psychophysical function relating proportional responding on $\mathrm{B}(\% \mathrm{~B})$ to time measured from the onset of the trial. This function has a logistic form, characterized by the indifference point, $T_{50}$ (the time at which $\% \mathrm{~B}=50$ ), and a slope parameter, $\varepsilon$; these parameters may be used to derive the Weber fraction, an index of the precision of temporal differentiation (see Killeen and Fetterman 1988; Gibbon et al. 1997; Ho et al. 2002). In the free-operant psychophysical procedure, the Weber fraction is generally expressed as the ratio of the limen ( $\left[T_{75}-T_{25}\right] / 2$, i.e., half the difference between the times corresponding to $\% \mathrm{~B}=75$ and $\% \mathrm{~B}=25$ ) to $T_{50}$. Thus, a low Weber fraction signifies a relatively steep psychometric function, in other words, precise temporal differentiation.

There is a substantial body of evidence for the involvement of central dopaminergic mechanisms in the control of interval timing behavior (see Meck 1996, 2006; Gibbon et al. 1997; Hinton and Meck 1997; Meck and Benson 2002; MacDonald and Meck 2004;). In the freeoperant psychophysical procedure, the psychostimulant $d$ amphetamine, which is known to release dopamine, produces a leftward shift in the psychophysical function, which is reflected as a reduction of $T_{50}$ (Chiang et al. 2000a; Cheung et al. 2006; Body et al. 2006b). The effects of $d$-amphetamine and other dopamine-releasing agents have generally been attributed to the stimulation of postsynaptic $\mathrm{D}_{2}$ dopamine receptors (Meck 1986, 1996). ${ }^{1}$ Consistent with this hypothesis, it has been found that the $\mathrm{D}_{2}$ dopamine receptor agonist quinpirole can reduce $T_{50}$ in the free-operant psychophysical procedure (Cheung et al. 2007a). However, it has recently been demonstrated that the selective $\mathrm{D}_{1}$ dopamine receptor agonist 6-chloro-2,3,4,5tetrahydro-1-phenyl-1H-3-benzazepine (SKF-81927) has a qualitatively similar effect on performance in the freeoperant psychophysical procedure to that of $d$-amphetamine (Cheung et al. 2007b). Moreover, the reduction of $T_{50}$ produced by $d$-amphetamine can be antagonized by a selective $\mathrm{D}_{1}$ dopamine receptor antagonist 8-bromo2,3,4,5-tetrahydro-3-methyl-5-phenyl-1H-3-benzazepin-7ol (SKF-83566), but not by the $\mathrm{D}_{2}$ receptor antagonist haloperidol (Cheung et al. 2007b), indicating an involvement of $\mathrm{D}_{1}$ dopamine receptors in $d$-amphetamine's effects on timing behavior in this schedule.

\footnotetext{
${ }^{1}$ Most drugs acting at $\mathrm{D}_{1}$ dopamine receptors do not discriminate between $D_{1}$ and $D_{5}$ dopamine receptors and are therefore more precisely designated $\mathrm{D}_{1}$-like receptor agonists and antagonists. Similarly, most drugs acting at $\mathrm{D}_{2}$ receptors do not discriminate between $D_{2}, D_{3}$, and $D_{4}$ receptors and are therefore designated $D_{2}$-like receptor agonists and antagonists (Alexander et al. 2008). Throughout this paper, for the sake of simplicity, they are referred to as $D_{1}$ and $D_{2}$ receptor agonists and antagonists.
}

Manipulation of the 5-hydroxytryptaminergic (5-HTergic) system has also been shown to influence timing performance in the free-operant psychophysical procedure. Administration of the $5-\mathrm{HT}_{2 \mathrm{~A} / 2 \mathrm{C}}$ receptor agonist DOI produces a leftward shift in the psychophysical curve, which can be attenuated by the $5-\mathrm{HT}_{2 \mathrm{~A}}$ receptor antagonists ketanserin and MDL-100907 (Body et al. 2003, 2006a). Interestingly, the highly selective $5-\mathrm{HT}_{2 \mathrm{~A}}$ receptor antagonist MDL-100907 is also able to attenuate the effect of $d$-amphetamine on timing performance in this schedule, suggesting a functional interaction between $\mathrm{D}_{1}$ dopamine receptors and $5-\mathrm{HT}_{2 \mathrm{~A}}$ receptors (Body et al. 2006b).

Displacement of the psychometric function in interval timing schedules is not the only behavioral effect of $d$-amphetamine that has been shown to depend upon 5-HTergic mechanisms. For example, $5-\mathrm{HT}_{2 \mathrm{~A}}$ receptor antagonists have been shown to antagonize $d$-amphetamineinduced hyperlocomotion (Sorenson et al. 1993; Moser et al. 1996; O’Neill et al. 1999) and $d$-amphetamine-induced disruption of latent inhibition (Moser et al. 1996). Forebrain 5-HT depletion has been found to attenuate some of $d$ amphetamine's behavioral effects, including the disruption of performance in the five-choice serial reaction time task and the reduction of tolerance of delay of reinforcement (Harrison et al. 1997; Winstanley et al. 2003). However, some behavioral effects of $d$-amphetamine appear to be impervious to central 5-HT depletion; for example, Fletcher et al. (1999) found no effect of 5-HT depletion on the reinforcing effect of $d$-amphetamine using a variety of selfadministration schedules. It is not known whether central 5-HT depletion alters the ability of $d$-amphetamine to displace the psychometric timing function.

The present experiment examined whether $d$-amphetamine's effect on temporal differentiation performance in the free-operant psychophysical procedure depends upon an intact 5-HTergic system. The effect of $d$-amphetamine on temporal differentiation was compared between intact rats and rats whose ascending 5-HTergic pathways had been ablated by injection of the selective neurotoxin 5,7dihydroxytryptamine into the dorsal and median raphe nuclei. In addition to $d$-amphetamine, an 'indirect' dopamine receptor agonist, we also examined the effects of a 'direct' $\mathrm{D}_{1}$ dopamine receptor agonist, SKF-81297, and a 'direct' $\mathrm{D}_{2}$ dopamine receptor agonist, quinpirole.

\section{Materials and methods}

The experiment was carried out in accordance with UK Home Office regulations governing experiments on living animals and was approved by the local ethical review committee. 
Subjects

Twenty-four female Wistar rats aged approximately 4 months and weighing $250-300 \mathrm{~g}$ at the start of the experiment were used. They were housed individually under a constant cycle of $12 \mathrm{~h}$ light and $12 \mathrm{~h}$ darkness (lights on at $0700-1900 \mathrm{~h}$ ) and were maintained at $80 \%$ of their initial free-feeding body weights by providing a limited amount of standard rodent diet after each experimental session. Tap water was freely available in the home cage.

\section{Surgery}

The rats received either lesions of the dorsal and median raphe nuclei $(n=11)$ or sham lesions $(n=13)$. Our methods for the surgical preparation of the rats have been described in detail elsewhere (Wogar et al. 1992). Rats were anesthetized with $4 \%$ isoflurane in oxygen and placed in a stereotaxic apparatus; anesthesia was maintained with $2 \%$ isoflurane in oxygen during the surgery. The following stereotaxic coordinates (Paxinos and Watson 1998) were used to locate the median and dorsal raphe nuclei: $\mathrm{AP}+1.2$, $\mathrm{L}, 0.0, \mathrm{DV}+1.5$ (dorsal) +3.5 (median), measured from the interaural line, with the incisor bar fixed $3.3 \mathrm{~mm}$ below the interaural line. The neurotoxin 5,7-dihydroxytryptamine hydrobromide (5,7-DHT; Sigma-Aldrich, Poole, UK) was injected into the median and dorsal raphe nuclei of the rats in the lesioned group; the control group received sham injections into the same areas. The dose of 5,7-DHT injected into the dorsal and median raphe nuclei was $4 \mu \mathrm{g}$ base dissolved in $1 \mu \mathrm{l}$ vehicle $(0.9 \%, w / v$ sodium chloride solution with $0.1 \%$ ascorbic acid) in each case. The injection rate was $0.1 \mu \mathrm{l}$ per $15 \mathrm{~s}$, and the cannula was left in position for a further $3 \mathrm{~min}$ after the completion of the injection in each site.

\section{Apparatus}

The rats were trained in operant conditioning chambers (Campden Instruments Limited, Sileby, UK) of internal dimensions $20 \mathrm{~cm} \times 23 \mathrm{~cm} \times 22.5 \mathrm{~cm}$. One wall of the chamber contained a recess into which a motor-operated dipper could deliver $50 \mu \mathrm{l}$ of a liquid reinforcer. Apertures were situated $5 \mathrm{~cm}$ above and $2.5 \mathrm{~cm}$ on either side of the recess; a motor-driven retractable lever could be inserted into the chamber through each aperture. Each lever could be depressed by a force of approximately $0.2 \mathrm{~N}$. The chamber was enclosed in a sound-attenuating chest; masking noise was provided by a rotary fan. Twelve chambers were used, and each rat was always tested in the same chamber. An Acorn microcomputer, programmed in Arachnid BASIC (CeNeS Ltd, Cambridge, UK), located in an adjoining room, controlled the schedules and recorded the behavioral data.
Behavioral training

Two weeks after surgery, the food deprivation regimen was introduced and the rats were gradually reduced to $80 \%$ of their free-feeding body weights. They were then trained to press the levers and were exposed to a discrete-trials continuous reinforcement schedule, in which the two levers were presented in random sequence, for three sessions. Thereafter, the rats underwent 50 min training sessions under the free-operant psychophysical procedure, 7 days a week, at the same time each day during the light phase of the daily cycle (between 0700 and $1400 \mathrm{~h}$ ). The reinforcer, a $0.6-\mathrm{M}$ solution of sucrose in distilled water, was prepared daily before each session.

The free-operant psychophysical procedure was identical to that used by Chiang et al. (1998, 2000a, b). Each session consisted of fifty 50 -s trials, successive trials being separated by 10 -s intertrial intervals. In 40 of the 50 trials, reinforcement was provided on a constant-probability variable-interval 30-s schedule (Catania and Reynolds 1968). The levers were inserted into the chamber at the start of each trial and were withdrawn during the intertrial interval. During the first $25 \mathrm{~s}$ of the trial, reinforcers were delivered only for responses on lever A, whereas during the last $25 \mathrm{~s}$, reinforcers were delivered only for responses on lever B. The positions of lever A and lever B (left versus right) were counterbalanced across subjects. Four of the 50 trials in each session were probe trials, in which no reinforcers were delivered. The remaining six trials were forced-choice trials, in which only one lever was present in the chamber (lever A three trials; lever B three trials). The probe and forced-choice trials were interspersed randomly among the standard trials, with the constraint that at least one standard trial occurred between successive probe or forced-choice trials. In the standard and probe trials, switching between the two levers was restricted to one switch per trial: in each trial, the first response on lever B triggered the withdrawal of lever A until the start of the next trial (Chiang et al. 1998).

\section{Drug treatment}

The drug treatment regimen started after $>90$ sessions of preliminary training under the free-operant psychophysical procedure. Injections of drugs were given on Tuesdays and Fridays and injections of vehicle-alone on Mondays and Thursdays; no injections were given on Wednesdays, Saturdays, or Sundays. In order to accrue a sufficient number of probe trials to obtain reliable estimates of the timing indices for individual rats, each active treatment was administered on five occasions, in a pseudorandom sequence. Subcutaneous (s.c.) injections were given using a 26-gauge needle at a volume of $1.0 \mathrm{ml} \mathrm{kg}^{-1}$; intraperitoneal 
(i.p.) injections were given using a 25-gauge needle at a volume of $2.5 \mathrm{ml} \mathrm{kg}^{-1}$.

(-)-Quinpirole hydrochloride $0.08 \mathrm{mg} \mathrm{kg}^{-1}, d$-amphetamine sulfate $0.4 \mathrm{mg} \mathrm{kg}^{-1}$, and 6-chloro-2,3,4,5-tetrahydro1-phenyl-1H-3-benzazepine $\mathrm{HBr}$ (SKF-81297) $0.8 \mathrm{mg} \mathrm{kg}^{-1}$ were dissolved in $0.9 \% \mathrm{NaCl}$ solution. Quinpirole and $d$ amphetamine were injected i.p. and SKF-81297 s.c. All injections were given $15 \mathrm{~min}$ before the start of the experimental session.

The doses of the drugs were selected on the basis of previous studies which had shown that these doses produced approximately equivalent effects on the timing performance of rats trained under the free-operant psychophysical procedure (see "Discussion" for references). Quinpirole and SKF-81297 were obtained from Tocris Cookson (Avonmouth, UK); $d$-amphetamine was obtained from Sigma (Poole, UK).

\section{Biochemical assays}

At the end of the experiment, the rats were killed, their brains removed, and the following areas were dissected out on ice: parietal cortex, hippocampus, amygdala, nucleus accumbens, and hypothalamus. The concentrations of 5HT, 5-hydroxyindoleacetic acid (5-HIAA), noradrenaline, and dopamine in each region were measured by highperformance liquid chromatography combined with electrochemical detection. The method was as described by Wogar et al. (1992), with the exception that the mobile phase for the indoleamine assay was $0.1 \mathrm{M}$ sodium citrate buffered to $\mathrm{pH} 2.45$ containing 75\% (w/v) acetonitrile and $1 \mathrm{mM}$ octanesulfonic acid (ion pair agent); $\mathrm{N}$ - $\omega$-methyl-5hydroxytryptamine was used as the internal standard in the indoleamine assay. The five brain regions included areas principally innervated by the median raphe nucleus (hippocampus), the dorsal raphe nucleus (nucleus accumbens), and by both nuclei (amygdala and neocortex; Imai et al. 1986).

\section{Data analysis}

Only the data collected from the probe trials were used in the analysis. The effects of the three drugs were analyzed separately. For each drug, comparisons were made between the data collected in the drug treatment sessions and the data collected in the immediately preceding sessions in which the vehicle alone was administered.

Relative response rate Each 50-s trial was divided into 5-s time-bins. The mean response rate on each lever in successive time-bins was calculated for each rat under each treatment condition. The data were analyzed by three-factor analyses of variance (group [sham lesion, 5,7-DHT lesion] $\times$ treatment [drug, vehicle] $\times$ time-bin) with repeated measures on the second and third factors.

Psychometric functions A two-parameter logistic function was fitted to the relative response rate data: $\% \mathrm{~B}=100 /(1+$ $\left[t / T_{50}\right]^{\varepsilon}$ ), where $t$ is time from trial onset, $T_{50}$ (the indifference point) is a parameter expressing the time at which $\% \mathrm{~B}=50 \%$, and $\varepsilon$ is the slope of the function (AlZahrani et al. 1996 ; $\varepsilon$ has a negative value in the case of ascending functions). The curve-fitting procedure yields estimates of the values of $T_{50}$ and $\varepsilon$, from which the Weber fraction was determined as follows. The limen was defined as half the difference between $T_{75}$ and $T_{25}\left(T_{75}\right.$ and $T_{25}$ are the values of $t$ corresponding to $\% \mathrm{~B}=75 \%$ and $\% \mathrm{~B}=25 \%$ ), and the Weber fraction was defined as limen $/ T_{50}$. Goodness of fit of the functions was expressed as the index of determination, $p^{2}$. The values of $T_{50}, \varepsilon$, and the Weber fraction derived from the individual subjects were analyzed using two-factor analyses of variance (group [sham lesion, 5,7-DHT lesion] $\times$ treatment [drug, vehicle]) with repeated measures on the latter factor.

Overall response rate Overall response rate, calculated for each rat under each treatment condition, was analyzed in the same way as the parameter values (see above).

A significance criterion of $P<0.05$ was used in all analyses.

\section{Results}

In both groups, under all treatment conditions, response rate on lever A declined and response rate on lever B increased as a function of time from trial onset, and the proportion of responding allocated to lever $\mathrm{B}(\% \mathrm{~B})$ increased progressively as a function of time from trial onset. Logistic psychometric functions provided a good description of the data, the mean values of $p^{2}$ being $>0.88$ under all treatment conditions in both groups (Table 1-3).

\section{Quinpirole}

The relative response rate $(\% \mathrm{~B})$ data are shown in Fig. 1. Quinpirole produced a leftward displacement of the timing function in both groups. Analysis of variance revealed significant main effects of treatment $[F(1,22)=12.5$, $P<0.01]$ and time-bin $[F(9,198)=322.2, P<0.001]$ and $\mathrm{a}$ significant treatment $\times$ time-bin interaction $[F(9,198)=5.8$, $P<0.001]$. There was no significant main effect of group, nor any significant interaction involving the group factor [all $F \mathrm{~s}<1]$.

The group mean values of the parameters of the psychometric functions and overall response rate $( \pm$ SEM) 
Table 1 Effect of quinpirole on quantitative timing parameters and overall response rate (mean $\pm \mathrm{SEM}$ )

\begin{tabular}{|c|c|c|c|c|}
\hline \multirow[t]{2}{*}{ Parameter } & \multicolumn{2}{|l|}{ Sham lesion } & \multicolumn{2}{|c|}{ 5,7-DHT lesion } \\
\hline & Vehicle & Quinpirole & Vehicle & Quinpirole \\
\hline Indifference point, $T_{50}(\mathrm{~s})$ & $14.7 \pm 1.8$ & $9.6 \pm 1.0^{*}$ & $14.5 \pm 1.5$ & $10.7 \pm 0.8^{*}$ \\
\hline Slope, $\varepsilon$ & $-4.3 \pm 0.4$ & $-3.9 \pm 0.9^{*}$ & $-5.2 \pm 0.6$ & $-3.1 \pm 0.3^{*}$ \\
\hline Weber fraction & $0.31 \pm 0.05$ & $0.40 \pm 0.05^{*}$ & $0.25 \pm 0.03$ & $0.40 \pm 0.04 *$ \\
\hline$p^{2}$ & $0.97 \pm 0.02$ & $0.98 \pm 0.01$ & $0.98 \pm 0.01$ & $0.98 \pm 0.01$ \\
\hline Overall response rate (responses $\min ^{-1}$ ) & $47.0 \pm 7.8$ & $29.2 \pm 4.2 *$ & $48.0 \pm 5.4$ & $31.1 \pm 3.0^{*}$ \\
\hline
\end{tabular}

${ }^{*} P<0.05$, significant difference from vehicle-alone condition

are shown in Table 1 and the effects of quinpirole on each variable (drug - vehicle differences) in the two groups are shown in Fig. 2.

Indifference point, $T_{50}$ Quinpirole reduced $T_{50}$ in both groups. There was a significant main effect of treatment $[F(1,22)=14.8, P<0.001]$; there was no significant effect of group and no significant group $\times$ treatment interaction $\left[F_{\mathrm{S}}<1\right]$.

Slope, $\varepsilon$ Quinpirole increased $\varepsilon$ in both groups (i.e., $\varepsilon$ was less strongly negative under the drug treatment condition than under the vehicle condition). The main effect of treatment was significant $[F(1,22)=5.1, P<0.05]$, but there was no significant group effect $[F<1]$ and no significant interaction $[F(1,22)=2.1$, NS $]$.

Weber fraction Quinpirole increased the Weber fraction in both groups. The main effect of treatment was significant
$[F(1,22)=9.4, P<0.01]$, but there was no significant group effect and no significant interaction $\left[F_{\mathrm{S}}<1\right]$.

Overall response rate Quinpirole reduced overall response rate in both groups. The effect of treatment was significant $[F(1,22)=38.9, P<0.001]$, but there was no significant group effect and no significant interaction $\left[F_{\mathrm{S}}<1\right]$.

\section{d-Amphetamine}

The relative response rate $(\% \mathrm{~B})$ data are shown in Fig. $3 . d$ Amphetamine produced a leftward displacement on the timing function in the sham-lesioned group, but not in the 5,7-DHT-lesioned groups. Analysis of variance revealed significant main effects of treatment $[F(1,22)=4.9, P<$ $0.05]$ and time-bin $[F(9,198)=278.1, P<0.001]$ and a significant treatment $\times$ time-bin interaction $[F(9,198)=7.2$, $P<0.001]$. There was no significant main effect of group,
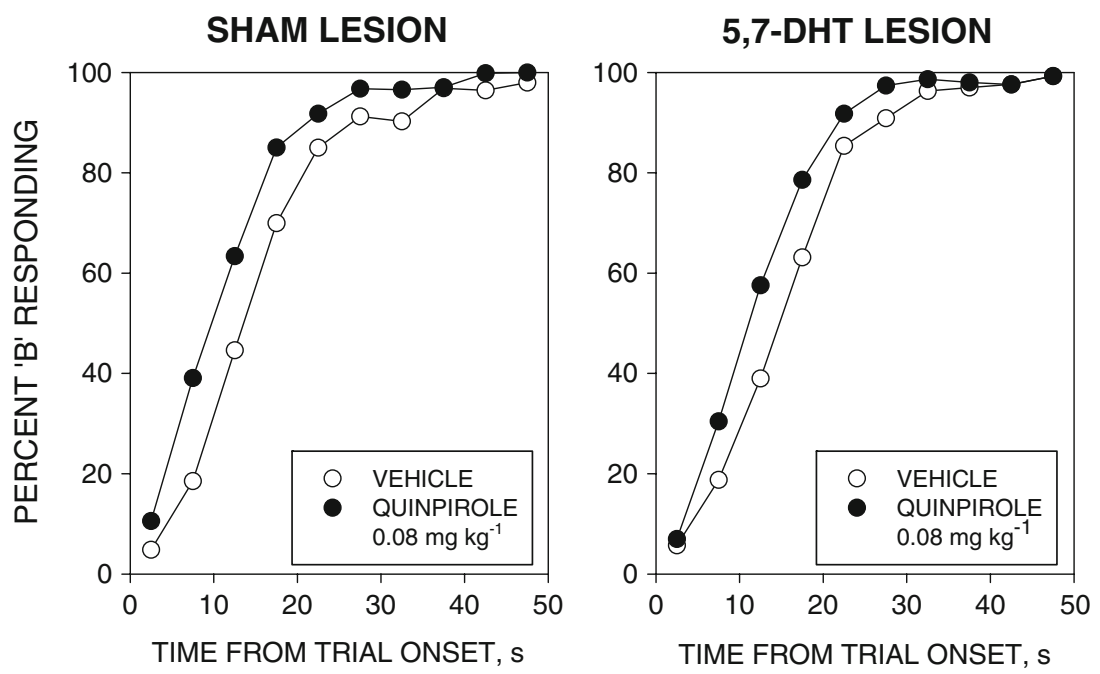

Fig. 1 Effects of quinpirole $0.08 \mathrm{mg} \mathrm{kg}^{-1}$ on performance in the freeoperant psychophysical procedure. Left-hand graph, data from intact (sham-lesioned) rats; right-hand graph, data from rats whose ascending 5-HTergic pathways had been destroyed by intra-raphe nucleus injection of 5,7-dihydroxytryptamine (5,7-DHT). Ordinates,

percent responding on lever B; abscissae, time from trial onset (s). Points show group mean data under each treatment condition (vehicle: white circles; quinpirole: black circles). Quinpirole displaced the psychometric function to the left in both groups 
Fig. 2 Effects of quinpirole $0.08 \mathrm{mg} \mathrm{kg}^{-1}$ on the indifference time $\left(T_{50}\right)$, the slope of the psychometric function $(\varepsilon)$, and the Weber fraction derived from the psychometric functions and the overall response rates for the individual rats in the sham-lesioned group (white columns) and the 5,7-

dihydroxytryptamine-lesioned group (black columns). Bars are group means + SEM. Quinpirole reduced $T_{50}$, increased $\varepsilon$ and the Weber fraction, and reduced overall response rate in both groups. There were no significant differences between the two groups
Fig. 3 Effects of $d$ amphetamine $0.4 \mathrm{mg} \mathrm{kg}^{-1}$ on performance in the free-operant psychophysical procedure (conventions as in Fig. 1). $d$-Amphetamine displaced the psychometric function to the left in the sham-lesioned group. This effect was attenuated in the 5,7DHT-lesioned group

\section{QUINPIROLE}
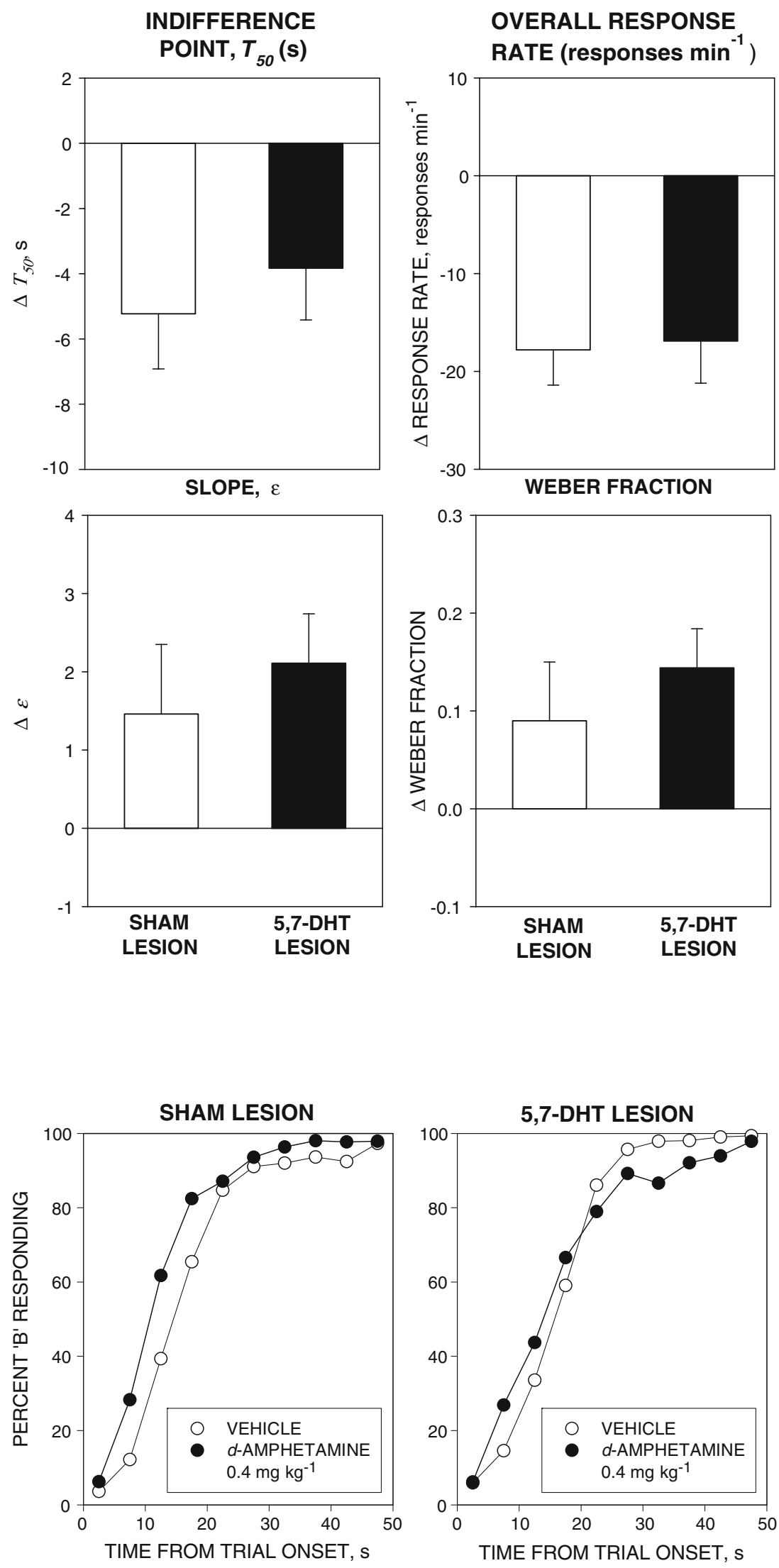
but the group $\times$ treatment interaction was significant $[F(1,22]=$ $5.3, P<0.05]$. The group $\times$ time-bin $[F(9,198)=1.6, \mathrm{NS}]$ and the three-way interaction $[F<1]$ were not statistically significant.

The group mean values of the parameters of the psychometric functions and overall response rate $( \pm$ SEM) are shown in Table 2 and the effects of $d$-amphetamine on each variable (drug - vehicle differences) in the two groups are shown in Fig. 4.

Indifference point, $T_{50} d$-Amphetamine reduced $T_{50}$ in the sham-lesioned group; this effect was considerably attenuated in the 5,7-DHT-lesioned group. This was reflected in the analysis of variance, which showed a significant main effect of treatment $[F(1,22)=11.8, P<0.01]$ and a significant group $\times$ treatment interaction $[F(1,22)=4.8, P<0.05]$. The main effect of group was not significant $[F<1]$.

Slope, $\varepsilon d$-Amphetamine did not significantly alter the value of $\varepsilon$. There was no significant main effect of treatment $[F(1,22)=3.7, \mathrm{NS}]$ or group $[F<1]$, and no significant interaction $[F<1]$.

Weber fraction $d$-Amphetamine did not significantly alter the Weber fraction. There was no significant main effect of treatment $[F(1,22)=4.0, \mathrm{NS}]$ or group $[F<1]$, and no significant interaction $[F<1]$.

Overall response rate $d$-Amphetamine reduced overall response rate in both groups. The effect of treatment was significant $[F(1,22)=38.0, P<0.001]$, but there was no significant group effect and no significant interaction $[F \mathrm{~S}<1]$.

SKF-81297

The relative response rate $(\% \mathrm{~B})$ data are shown in Fig. 5. SKF-81297 produced a leftward displacement on the timing function in both groups. Analysis of variance revealed significant main effects of treatment $[F(1,22)=20.0, P<$ $0.001]$ and time-bin $[F(9,198)=307.7, P<0.001]$ and a significant treatment $\times$ time-bin interaction $[F(9,198)=$ 11.4, $P<0.001]$. There was no significant main effect of group, nor any significant interaction involving the group factor [all $\left.F_{\mathrm{S}}<1\right]$.

The group mean values of the parameters of the psychometric functions and overall response rate $( \pm$ SEM) are shown in Table 3 and the effects of SKF-81297 on each variable (drug - vehicle differences) in the two groups are shown in Fig. 6.

Indifference point, $T_{50} \mathrm{SKF}-81297$ reduced $T_{50}$ in both groups. There was a significant main effect of treatment $[F(1$, $22)=21.6, P<0.001]$; there was no significant effect of group and no significant group $\times$ treatment interaction $\left[F_{\mathrm{S}}<1\right]$.

Slope, $\varepsilon$ SKF-81297 increased $\varepsilon$ in both groups. The main effect of treatment was significant $[F(1,22)=10.4, P<0.01]$, but there was no significant group effect and no significant interaction $[F \mathbf{S}<1]$.

Weber fraction SKF-81297 increased the Weber fraction in both groups. The main effect of treatment was significant $[F(1,22)=14.4, P<0.01]$, but there was no significant group effect and no significant interaction $\left[F_{\mathrm{S}}<1\right]$.

Overall response rate SKF-81297 reduced overall response rate in both groups. The effect of treatment was significant $[F(1,22)=64.4, P<0.001]$, but there was no significant group effect and no significant interaction $\left[F_{\mathrm{S}}<1\right]$.

\section{Biochemical data}

Table 4 shows the concentrations of 5-HT and 5-HIAA, noradrenaline, and dopamine in the brain areas of the rats belonging to the two groups. The levels of 5-HT and 5-

Table 2 Effect of $d$-amphetamine on quantitative timing parameters and overall response rate (mean \pm SEM)

\begin{tabular}{|c|c|c|c|c|}
\hline \multirow[t]{2}{*}{ Parameter } & \multicolumn{2}{|c|}{ Sham lesion } & \multicolumn{2}{|c|}{ 5,7-DHT lesion } \\
\hline & Vehicle & $d$-Amphetamine & Vehicle & $d$-Amphetamine \\
\hline Indifference point, $T_{50}(\mathrm{~s})$ & $15.9 \pm 1.9$ & $11.4 \pm 1.3^{*}$ & $14.8 \pm 1.2$ & $13.8 \pm 1.5$ \\
\hline Slope, $\varepsilon$ & $-5.0 \pm 0.6$ & $-4.0 \pm 0.4$ & $-4.7 \pm 0.6$ & $-3.6 \pm 0.7$ \\
\hline Weber fraction & $0.28 \pm 0.05$ & $0.34 \pm 0.06$ & $0.28 \pm 0.04$ & $0.46 \pm 0.09$ \\
\hline$p^{2}$ & $0.97 \pm 0.01$ & $0.94 \pm 0.04$ & $0.98 \pm 0.01$ & $0.94 \pm 0.02$ \\
\hline Overall response rate (responses $\min ^{-1}$ ) & $47.3 \pm 6.8$ & $32.5 \pm 7.3^{*}$ & $47.0 \pm 5.5$ & $27.8 \pm 4.7 *$ \\
\hline
\end{tabular}

$* P<0.05$, significant difference from vehicle-alone condition 
Fig. 4 Effects of $d$ the indifference time $\left(T_{50}\right)$, the slope of the psychometric function $(\varepsilon)$, and the Weber fraction derived from the psychometric functions and overall response rate (conventions as in Fig. 2). $d$ Amphetamine reduced $T_{50}$ in the sham-lesioned group; this effect was significantly attenuated in the 5,7-DHT-lesioned group (significance of between group difference, $* P<0.05$ ). Response rate was reduced in both groups amphetamine $0.4 \mathrm{mg} \mathrm{kg}^{-1}$ on
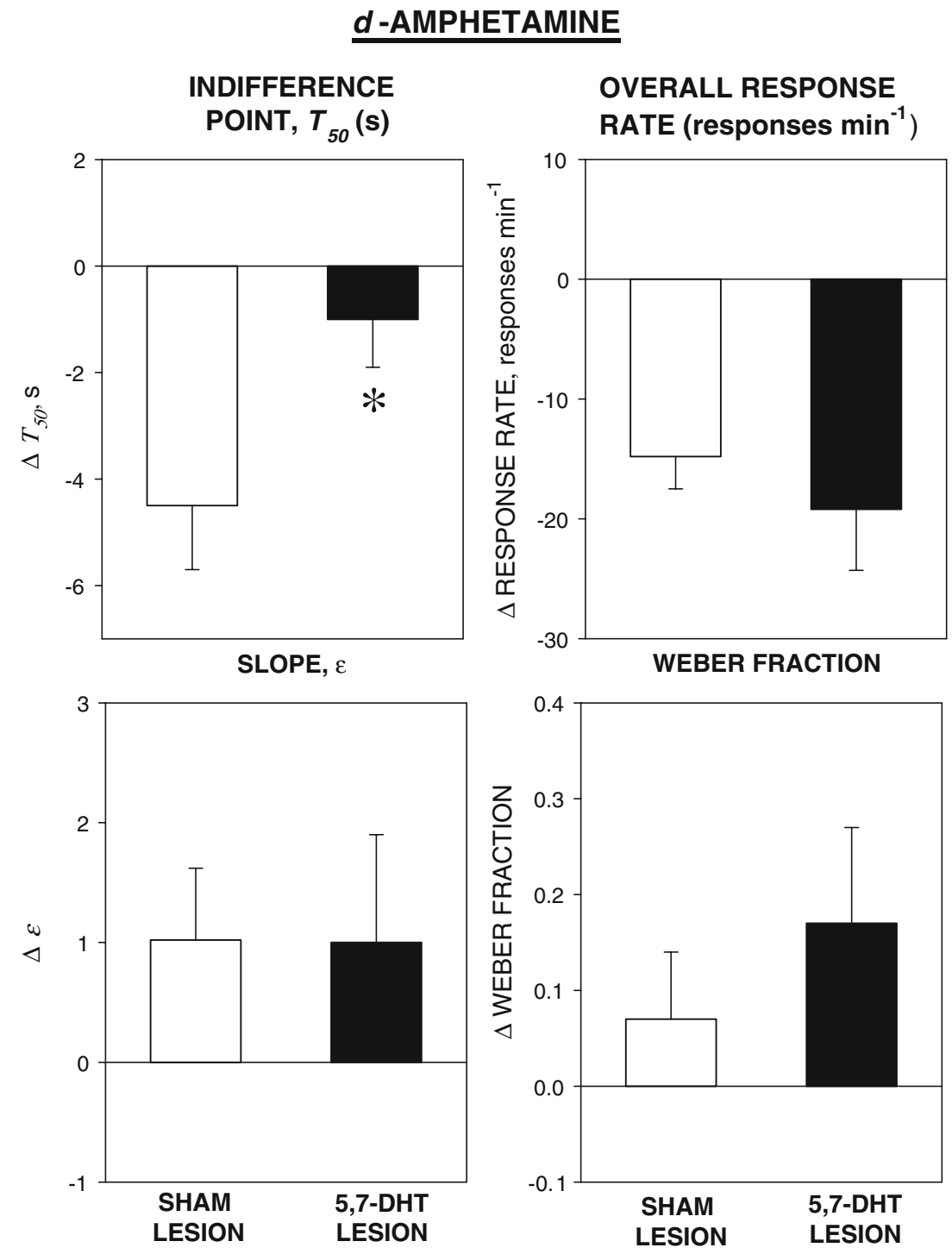

Fig. 5 Effects of SKF-81297 $0.8 \mathrm{mg} \mathrm{kg}^{-1}$ on performance in the free-operant psychophysical procedure (conventions as in Fig. 1). SKF-81297 displaced the psychometric function to the left in both groups
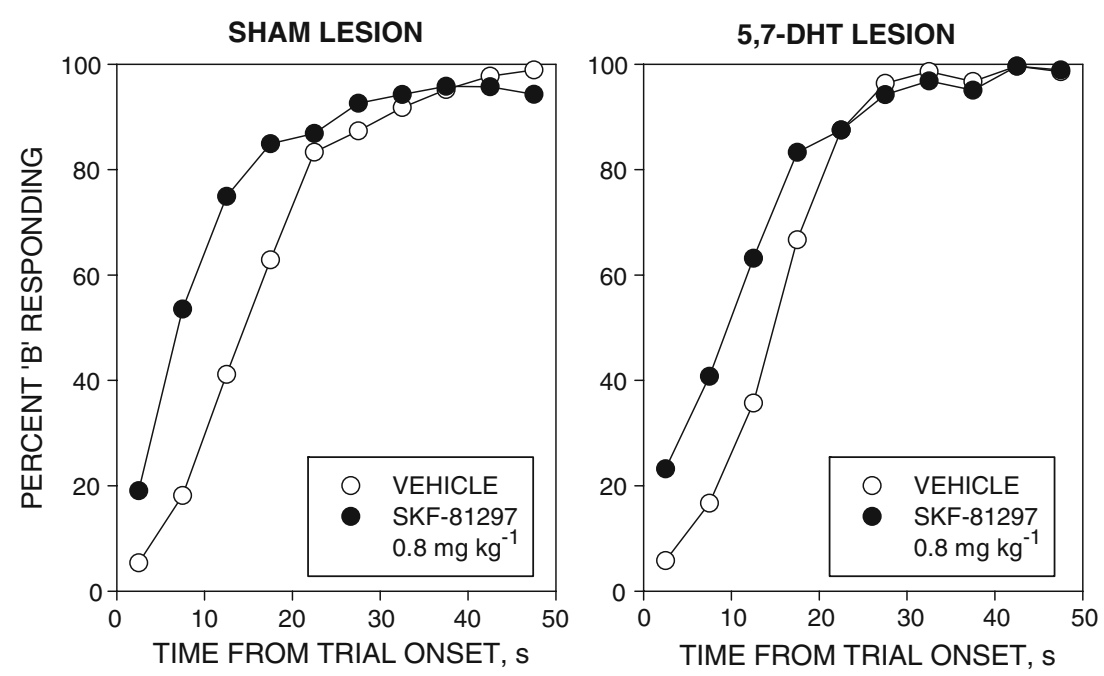
Table 3 Effect of SKF-81297 on quantitative timing parameters and overall response rate (mean \pm SEM)

\begin{tabular}{|c|c|c|c|c|}
\hline \multirow[t]{2}{*}{ Parameter } & \multicolumn{2}{|l|}{ Sham lesion } & \multicolumn{2}{|c|}{ 5,7-DHT lesion } \\
\hline & Vehicle & SKF-81297 & Vehicle & SKF-81297 \\
\hline Indifference point, $T_{50}(\mathrm{~s})$ & $14.8 \pm 2.0$ & $7.8 \pm 1.2^{*}$ & $14.1 \pm 1.1$ & $9.0 \pm 1.4^{*}$ \\
\hline Slope, $\varepsilon$ & $-4.3 \pm 0.5$ & $-3.1 \pm 0.5^{*}$ & $-4.6 \pm 0.5$ & $-2.6 \pm 0.4^{*}$ \\
\hline Weber fraction & $0.33 \pm 0.06$ & $0.51 \pm 0.09 *$ & $0.28 \pm 0.04$ & $0.56 \pm 0.07 *$ \\
\hline$p^{2}$ & $0.98 \pm 0.06$ & $0.88 \pm 0.03$ & $0.98 \pm 0.01$ & $0.89 \pm 0.03$ \\
\hline Overall response rate (responses $\min ^{-1}$ ) & $49.3 \pm 7.3$ & $15.3 \pm 1.9^{*}$ & $47.2 \pm 5.6$ & $15.8 \pm 1.8^{*}$ \\
\hline
\end{tabular}

$* P<0.05$, significant difference from vehicle-alone condition

HIAA in the lesioned group reduced by $>80 \%$ compared to the sham-lesioned group in all areas assayed [ $t$ test: $P<0.001$ in each case]. There was no significant effect of the lesion on the levels of the catecholamines in any brain region examined.

\section{Discussion}

In agreement with previous findings with Stubbs' freeoperant psychophysical procedure (Stubbs 1976; Bizo and White 1994a, b; Chiang et al. 2000a, b; Machado and
Fig. 6 Effects of SKF-81297 $0.8 \mathrm{mg} \mathrm{kg}^{-1}$ on the indifference time $\left(T_{50}\right)$, the slope of the psychometric function $(\varepsilon)$, and the Weber fraction derived from the psychometric functions and overall response rate (conventions as in Fig. 2). SKF81297 reduced $T_{50}$, increased $\varepsilon$ and the Weber fraction, and reduced overall response rate in both groups. There were no significant differences between the two groups

\section{SKF-81297}
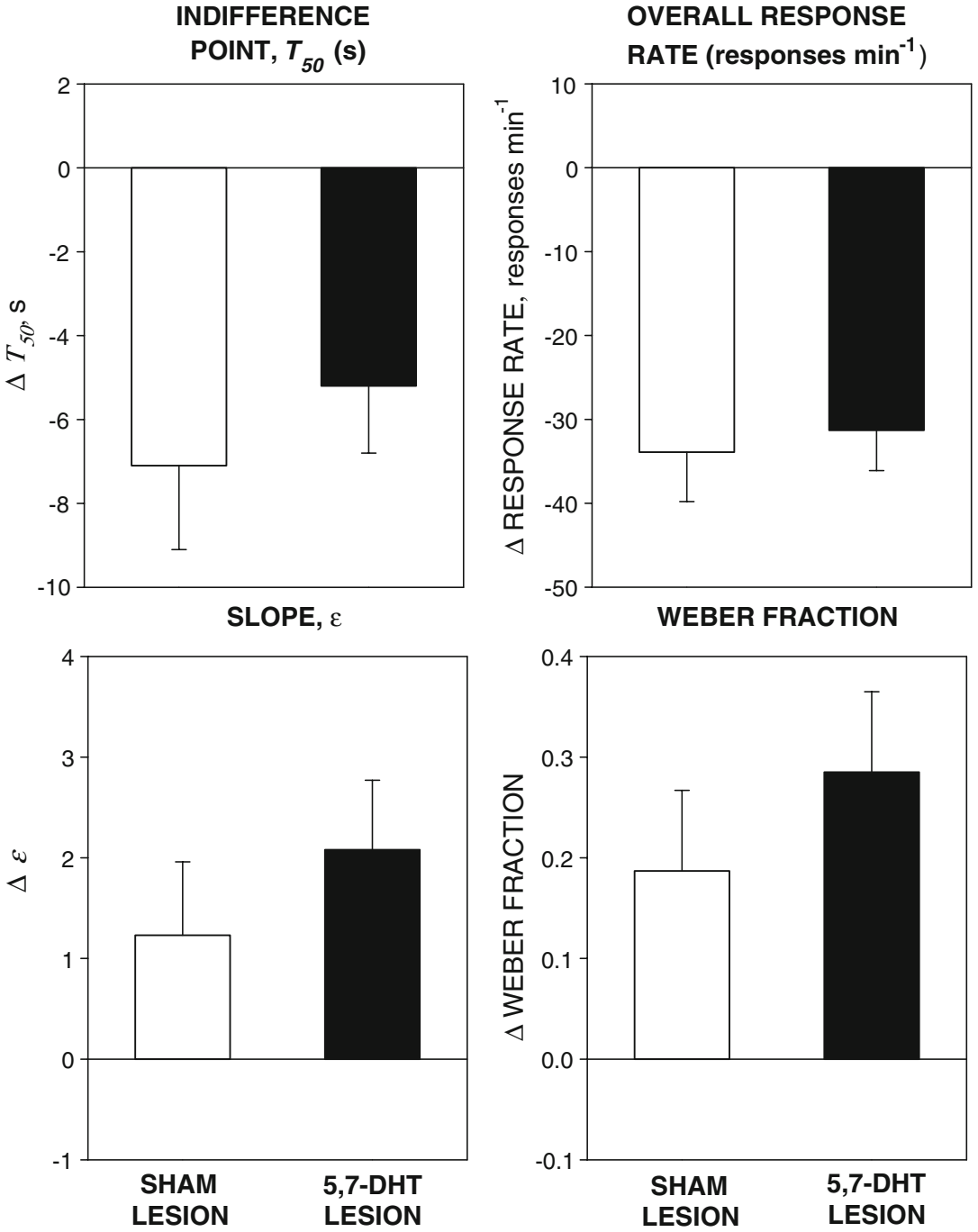
Table 4 Concentrations of monoamines in the brains of the 5,7-DHTlesioned and sham-lesioned groups

\begin{tabular}{|c|c|c|c|}
\hline \multirow[t]{2}{*}{ Region } & \multicolumn{3}{|c|}{ Concentration (ng g ${ }^{-1}$, wet weight) \pm SEM } \\
\hline & $\begin{array}{l}\text { Sham } \\
\text { lesion }\end{array}$ & $\begin{array}{l}5,7-\mathrm{DHT} \\
\text { lesion }\end{array}$ & $\begin{array}{l}\text { Percent } \\
\text { sham }\end{array}$ \\
\hline \multicolumn{4}{|l|}{ 5-HT } \\
\hline Parietal cortex & $235 \pm 15$ & $43 \pm 10$ & $18.2 *$ \\
\hline Hippocampus & $315 \pm 19$ & $43 \pm 9$ & $13.7 *$ \\
\hline Amygdala & $635 \pm 30$ & $62 \pm 10$ & $9.7 *$ \\
\hline Nucleus accumbens & $769 \pm 56$ & $63 \pm 16$ & $8.2 *$ \\
\hline Hypothalamus & $805 \pm 36$ & $105 \pm 22$ & $13.1^{*}$ \\
\hline \multicolumn{4}{|l|}{ Noradrenaline } \\
\hline Parietal cortex & $235 \pm 7$ & $214 \pm 9$ & 91.3 \\
\hline Hippocampus & $331 \pm 9$ & $310 \pm 9$ & 93.6 \\
\hline Amygdala & $435 \pm 9$ & $425 \pm 11$ & 97.6 \\
\hline Nucleus accumbens & $197 \pm 19$ & $186 \pm 15$ & 94.7 \\
\hline Hypothalamus & $1093 \pm 88$ & $1149 \pm 70$ & 105.1 \\
\hline \multicolumn{4}{|l|}{ 5-HIAA } \\
\hline Parietal cortex & $190 \pm 9$ & $17 \pm 5$ & $9.1 *$ \\
\hline Hippocampus & $327 \pm 17$ & $27 \pm 5$ & $8.1 *$ \\
\hline Amygdala & $503 \pm 22$ & $47 \pm 11$ & $9.3 *$ \\
\hline Nucleus accumbens & $635 \pm 30$ & $48 \pm 13$ & $7.5^{*}$ \\
\hline Hypothalamus & $710 \pm 81$ & $100 \pm 18$ & $14.1^{*}$ \\
\hline \multicolumn{4}{|l|}{ Dopamine } \\
\hline Parietal cortex & $193 \pm 26$ & $184 \pm 23$ & 95.7 \\
\hline Hippocampus & $35 \pm 4$ & $32 \pm 4$ & 89.7 \\
\hline Amygdala & $553 \pm 36$ & $546 \pm 31$ & 98.7 \\
\hline Nucleus accumbens & $5072 \pm 319$ & $4936 \pm 296$ & 97.3 \\
\hline Hypothalamus & $367 \pm 19$ & $393 \pm 16$ & 107.1 \\
\hline
\end{tabular}

$* P<0.001$, significant difference between groups

Guilhardi 2000; Body et al. 2003, 2004, 2006a, b; Cheung et al. 2006, 2007a, b, c), response rate on lever A declined, while response rate on lever B increased, as a function of time from trial onset, this being reflected in an increasing percentage of total responding being devoted to lever B (\% B) as the trial progressed. The schedule employed in these experiments was the 'constrained-switching' version of the free-operant psychophysical procedure, in which the first response on lever B in each trial results in removal of lever A from the operant chamber; this has the advantage of precluding repetitive switching between the levers (Chiang et al. 1998). This version of the schedule results in more precise temporal differentiation (steeper psychometric functions and lower Weber fractions) than the conventional ('unconstrained switching') version, in which the subject is able to freely switch back and forth between the two levers throughout the trial (Chiang et al. 1998, 1999, 2000a, b). It is noteworthy that in these experiments the values of $T_{50}$ are considerably shorter than the 'transition point' (the point at which reinforcer allocation was changed from lever A to lever B) of $25 \mathrm{~s}$ from trial onset. This appears to be a feature of the constrained switching version of this task as other experiments using this schedule consistently report values of $T_{50}$ that are shorter than the 'transition point' (Chiang et al. 1998, 1999, 2000a, b; Body et al. 2004, 2006a, b; Cheung et al. 2006, 2007a, b, c). The reason for this discrepancy between the value of $T_{50}$ and the 'transition point' in the constrained switching version of the free-operant psychophysical procedure remains unclear. One possible explanation (Ho et al. 1998) is that the first reinforcer delivered for responding on lever $\mathrm{B}$ strengthens the act of switching from A to B, resulting in a tendency to switch 'early'; since switching from B to A is not permitted by the schedule, early switching is reflected in a shortening of $T_{50}$. Although intuitively reasonable, this interpretation fails to account for the finding of Chiang et al. $(1998,1999)$ that the value of $T_{50}$ was not affected by removal and reinstatement of the constraint on switching, or for the finding by Chiang et al. (1999) and others (Al-Zahrani et al. 1996; Al-Ruwaitea et al. 1999; Body et al. 2001) that central 5-HT depletion markedly facilitates switching on a number of concurrent schedule procedures, including the free-operant psychophysical procedure, without significantly altering the steady-state value of $T_{50}$.

In both groups, quinpirole and SKF-81297 reduced the value of $T_{50}$; this is consistent with previous findings with these drugs (Cheung et al. 2007a, b). Quinpirole is a $\mathrm{D}_{2}$ like dopamine receptor agonist with high affinity for $\mathrm{D}_{2}$, $D_{3}$, and $D_{4}$ receptors and very little affinity for $D_{1}$ dopamine receptors or 5-HT receptors (Sokoloff et al. 1990; Van Tol et al. 1991; Levant et al. 1992; Seeman and Van Tol 1994; Tang et al. 1994; Millan et al. 2002; Moreland et al. 2004). Quinpirole's effect on temporal differentiation performance in the free-operant psychophysical procedure has previously been shown to be attenuated by the " $\mathrm{D}_{2}$ receptor-preferring" antagonists haloperidol, eticlopride, and sulpiride, but not by the selective $\mathrm{D}_{3}$ receptor antagonist nafadotride, the selective $\mathrm{D}_{4}$ receptor antagonist L-745870, or the selective $\mathrm{D}_{1}$ receptor antagonist SKF-83566 (Cheung et al. 2007a). SKF-81297 has also been previously shown to decrease the value of $T_{50}$ in this schedule, an effect which is antagonized by the $\mathrm{D}_{1}$ receptor antagonist SKF-83566, but not by haloperidol (Cheung et al. 2007b). The inability of 5-HT depletion to modify the effects of quinpirole and SKF-81297 suggests that the effect of direct stimulation of $\mathrm{D}_{1}$ and $\mathrm{D}_{2}$ dopamine receptors by agonists selective for these receptor subtypes is not dependent on an intact 5-HTergic system.

In the sham-lesioned group, $d$-amphetamine produced a leftward displacement of the psychometric function and a corresponding decrease in $T_{50}$, consistent with previous findings (Chiang et al. 2000a; Cheung et al. 2006; Body et al. 2006b). This effect of $d$-amphetamine was attenuated by depletion of forebrain 5-HT in the 5,7-dihydroxytryptaminelesioned group, indicating that an intact 5-HTergic system is 
required for $d$-amphetamine to exert its effects on temporal differentiation (see below).

The doses of the three agonists used in this experiment were selected on the basis of previous experiments with $d$ amphetamine (Chiang et al. 2000a; Cheung et al. 2006; Body et al. 2006b), quinpirole (Cheung et al. 2007a,c), and SKF-81297 (Cheung et al. 2007b), which indicated that these doses produced approximately equivalent effects on $T_{50}$ in the free-operant psychophysical procedure. Visual inspection of the present data suggests that $d$-amphetamine had a somewhat smaller effect than the other two agonists (see Figs. 1, 3, and 5). It should be noted that only a single dose of each agonist was employed in this experiment, and therefore it is not possible to state whether the diminished ability of $d$-amphetamine to reduce $T_{50}$ following 5 -HT depletion would have been surmountable with higher doses.

The mechanisms underlying $d$-amphetamine's effect on temporal differentiation performance in the free-operant psychophysical procedure remain unclear at this time. The present results, together with the evidence reviewed above, indicate that both dopaminergic and 5-HTergic mechanisms are likely to be involved. It is well established that $d$ amphetamine promotes the release not only of dopamine but also of 5-HT and noradrenaline (Fuxe and Ungerstedt 1970; Kucenski and Segal 1989; Seiden and Sabol 1993; Rothman et al. 2001), raising the possibility that $d$ amphetamine's effect on $T_{50}$ is brought about by the simultaneous release of dopamine and 5-HT. However, if that were the case, it might be expected that blockade of both $\mathrm{D}_{1}$ dopamine receptors and $5-\mathrm{HT}_{2 \mathrm{~A}}$ receptors would be needed in order to produce a complete antagonism of $d$ amphetamine's effect on $T_{50}$. The fact that $d$-amphetamine's effect on timing performance could be completely abolished by blockade of either $\mathrm{D}_{1}$ receptors or $5-\mathrm{HT}_{2 \mathrm{~A}}$ receptors (Body et al. 2006b; Cheung et al. 2006, 2007b) suggests a serial rather than a parallel arrangement of dopaminergic and 5-HTergic mechanisms. One possibility is that 5-HTergic mechanisms may play a "permissive" role in dopamine release. Such a mechanism could account for the loss of $d$-amphetamine's effect and the survival of quinpirole's and SKF-81297's effects following central 5-HT depletion. Thus, 5-HT depletion may reduce $d$-amphetamine's ability to release dopamine from presynaptic terminals, whereas it would not be expected to affect the interaction of directly acting agonists with postsynaptic $\mathrm{D}_{1}$ and $\mathrm{D}_{2}$ dopamine receptors. The involvement of such a mechanism in the regulation of interval timing is speculative. However, there is evidence that $5-\mathrm{HT}_{2 \mathrm{~A}}$ receptor-mediated facilitation of dopamine release occurs in the striatum and medial prefrontal cortex (Sershen et al. 2000; Pehek et al. 2001; Alex and Pehek 2007).

The lesion employed in the present experiment entailed "global" depletion of 5-HT from the forebrain, and therefore does not provide information about the anatomical location of the 5-HT-dopamine interaction underlying $d$ amphetamine's effects on interval timing. Further work using local destruction of 5-HTergic terminals in different regions will be needed to address this question. Subregions of the corpus striatum and prefrontal cortex may be suitable initial targets for this endeavor, as these regions have been implicated in the control of interval timing (Gibbon et al. 1997; Meck and Benson 2002; Matell and Meck 2004; Meck 2006).

The present experiment did not seek to identify the species of 5-HT receptor that may be involved in $d$ amphetamine's effects on timing performance. Previous experiments have shown that $5-\mathrm{HT}_{2 \mathrm{~A}}$ receptor stimulation can displace the psychometric timing function to the left in the free-operant psychophysical procedure and other immediate timing schedules (e.g., Body et al. 2004; Asgari et al. 2006). Our recent finding that $d$-amphetamine's effect on temporal differentiation could be antagonized by the selective 5- $\mathrm{HT}_{2 \mathrm{~A}}$ receptor antagonist MDL-100907 (Body et al. 2006b) is consistent with the notion that $5-\mathrm{HT}_{2 \mathrm{~A}}$ receptor stimulation is an important component of 5-HTdopamine interactions that may be involved in regulating interval timing behavior. The location of these $5-\mathrm{HT}_{2 \mathrm{~A}}$ receptors is uncertain and requires further investigation. The dorsal striatum is an unlikely candidate, despite its putative key role in interval timing (Gibbon et al. 1997; Meck and Benson 2002; Matell and Meck 2004; Meck 2006), since direct injection of the $5-\mathrm{HT}_{2 \mathrm{~A} / 2 \mathrm{C}}$ receptor agonist DOI into this region was found not to affect timing performance (Body et al. 2006a).

$5-\mathrm{HT}_{2 \mathrm{~A}}$ receptors are not the only type of 5-HT receptor that mediate effects on timing performance; $5-\mathrm{HT}_{1 \mathrm{~A}}$ receptor stimulation has been shown to exert a qualitatively similar effect to $5-\mathrm{HT}_{2 \mathrm{~A}}$ receptor stimulation on temporal differentiation in the free-operant psychophysical procedure (Body et al. 2002, 2004) and the fixed-interval peak procedure (Asgari et al. 2006). Interestingly, it has been proposed that $5-\mathrm{HT}_{1 \mathrm{~A}}$ receptors may regulate dopamine release in the prefrontal cortex, and that this may constitute a final common pathway of the action of atypical antipsychotics (Bantick et al. 2001; Ichikawa et al. 2001). The possible involvement of $5-\mathrm{HT}_{1 \mathrm{~A}}$ receptors in $d$ amphetamine's effect on timing behavior has yet to be investigated.

Both quinpirole and SKF-812997 increased the Weber fraction, indicating a reduction of the precision of temporal differentiation. In neither case was there a differential effect in the two groups. $d$-Amphetamine appeared to have a qualitatively similar effect, although the change in the Weber fraction was not statistically significant in this case. It is doubtful whether this reflects a true difference between the effects of $d$-amphetamine and the direct receptor 
agonists, as several previous studies have found a statistically significant effect of $d$-amphetamine on the Weber fraction (Chiang et al. 2000a; Cheung et al. 2006, 2007c).

In agreement with previous findings (Body et al. 2006b; Cheung et al. 2006, 2007a, b), $d$-amphetamine, quinpirole, and SKF-81297 all produced significant reductions of overall response rate. Interestingly, $d$-amphetamine's effect on response rate was not affected by 5-HT depletion. This suggests that while $d$-amphetamine's effect on temporal differentiation requires an intact 5-HTergic system, its effect on overall response rate does not. This finding also provides additional support for the claim that different mechanisms are involved in the effects of psychostimulants on timing performance and overall response rate (Chiang et al. 2000a; Odum et al. 2002; Body et al. 2004; Cheung et al. 2007a, b).

Acknowledgments This work was supported by the BBSRC. We are grateful to Mrs. V.K. Bak and Mr. R.W. Langley for their skilled technical help.

Open Access This article is distributed under the terms of the Creative Commons Attribution Noncommercial License which permits any noncommercial use, distribution, and reproduction in any medium, provided the original author(s) and source are credited.

\section{References}

Alex KD, Pehek EA (2007) Pharmacologic mechanisms of serotonergic regulation of dopamine neurotransmission. Pharmacol Ther 113:296-320

Alexander SPH, Mathie A, Peters JA (2008) Guide to receptors and channels (GRAC), 3rd edition. Br J Pharmacol 153(suppl. 2):S1S209

Asgari K, Body S, Zhang Z, Fone KCF, Bradshaw CM, Szabadi E (2006) Effects of 5-HT $1 \mathrm{~A}$ and $5-\mathrm{HT}_{2 \mathrm{~A}}$ receptor stimulation on temporal differentiation performance in the fixed-interval peak procedure. Behav Processes 71:250-257

Al-Ruwaitea ASA, Chiang T-J, Ho M-Y, Bradshaw CM, Szabadi E (1999) Effect of central 5-hydroxytryptamine depletion on changeover behaviour in concurrent schedules of reinforcement. Psychopharmacology 144:264-271

Al-Zahrani SSA, Ho MY, Velazquez Martinez DN, Lopez-Cabrera M, Bradshaw CM, Szabadi E (1996) Effect of destruction of the 5hydroxytryptaminergic pathways on behavioural timing and "switching" in a free-operant psychophysical procedure. Psychopharmacology 127:346-352

Bantick RA, Deakin JFW, Grasby PM (2001) The 5-HT1A receptor in schizophrenia: promising target for novel atypical neuroleptics? J Psychopharmacol 15:37-46

Bizo LA, White KG (1994a) The behavioural theory of timing: reinforcer rate determines pacemaker rate. J Exp Anal Behav 61:19-33

Bizo LA, White KG (1994b) Pacemaker rate and the behavioural theory of timing. J Exp Psychol Anim Behav Processes 20:308321

Body S, Chiang T-J, Mobini S, Ho M-Y, Bradshaw CM, Szabadi E (2001) Failure of central 5-hydroxytryptamine depletion to alter the effect of 8 -hydroxy-2-(di- $n$-propylamino)tetralin (8-OH-DPAT) on timing performance on the free-operant psychophysical procedure. Psychopharmacology 58:305-313

Body S, Kheramin S, Mobini S, Ho M-Y, Velasquez-Martinez DN, Bradshaw CM, Szabadi E (2002) Antagonism by WAY-100635 of the effects of 8-OH-DPAT on performance on a free-operant timing schedule in intact and 5-HT-depleted rats. Behav Pharmacol 13:603-614

Body S, Kheramin S, Ho MY, Miranda F, Bradshaw CM, Szabadi E (2003) Effects of a 5-HT2 receptor agonist, DOI (2,5-dimethoxy4-iodoamphetamine), and antagonist, ketanserin, on the performance on a free-operant timing schedule. Behav Pharmacol 14:599-607

Body S, Kheramin S, Ho M-Y, Miranda Herrera F, Bradshaw CM, Szabadi E (2004) Effects of fenfluramine on free-operant timing behaviour: evidence for involvement of $5-\mathrm{HT}_{2 \mathrm{~A}}$ receptors. Psychopharmacology 176:154-156

Body S, Asgari K, Cheung THC, Bezzina G, Fone KCF, Glennon JC, Bradshaw CM, Szabadi E (2006a) Evidence that the effect of 5$\mathrm{HT}_{2}$ receptor stimulation on temporal differentiation is not mediated by receptors in the dorsal striatum. Behav Processes 71:258-267

Body S, Cheung THC, Bezzina G, Asgari K, Fone KCF, Glennon JC, Bradshaw CM, Szabadi E (2006b) Effects of $d$-amphetamine and DOI (2,5-dimethoxy-4-iodoamphetamine) on timing behaviour: interaction between $\mathrm{D}_{1}$ and $5-\mathrm{HT}_{2 \mathrm{~A}}$ receptors. Psychopharmacology 189:331-343

Catania AC, Reynolds GS (1968) A quantitative analysis of the responding maintained by interval schedules of reinforcement. $\mathrm{J}$ Exp Anal Behav 11:327-383

Cheung THC, Bezzina G, Asgari K, Body S, Fone KCF, Bradshaw CM, Szabadi S (2006) Evidence for a role of $\mathrm{D}_{1}$ dopamine receptors in the effect of $d$-amphetamine on temporal differentiation performance in the free-operant psychophysical procedure. Psychopharmacology 185:378-388

Cheung THC, Bezzina G, Hampson CL, Body S, Fone KCF, Bradshaw CM, Szabadi E (2007a) Effect of quinpirole on timing behaviour in the free-operant psychophysical procedure: evidence for the involvement of $\mathrm{D}_{2}$ dopamine receptors. Psychopharmacology 193:423-436

Cheung THC, Bezzina G, Hampson CL, Body S, Fone KCF, Bradshaw CM, Szabadi E (2007b) Evidence for the sensitivity of operant timing behaviour to stimulation of $\mathrm{D}_{1}$ dopamine receptors. Psychopharmacology 195:213-222

Cheung THC, Bezzina G, Body S, Fone KCF, Bradshaw CM, Szabadi $\mathrm{E}(2007 \mathrm{c})$ Tolerance to the effect of 2,5-dimethoxy-4-iodoamphetamine (DOI) on free-operant timing behaviour: interaction between behavioural and pharmacological mechanisms. Psychopharmacology 192:521-535

Chiang TJ, Al-Ruwaitea AS, Ho MY, Bradshaw CM, Szabadi E (1998) The influence of 'switching' on the psychometric function in the free-operant psychophysical procedure. Behav Processes 44:197-209

Chiang TJ, Al-Ruwaitea ASA, Ho MY, Bradshaw CM, Szabadi E (1999) Effect of central 5-hydroxytryptamine depletion on performance on the free-operant psychophysical procedure: facilitation of switching, but no effect on temporal differentiation of responding. Psychopharmacology 143:166-173

Chiang TJ, Al-Ruwaitea AS, Mobini S, Ho MY, Bradshaw CM, Szabadi $\mathrm{E}$ (2000a) The effect of $d$-amphetamine on performance on two operant timing schedules. Psychopharmacology 150:170-184

Chiang TJ, Al-Ruwaitea AS, Mobini S, Ho MY, Bradshaw CM, Szabadi E (2000b) Effects of 8-hydroxy-2-(di-n-propylamino) tetralin (8-OH-DPAT) on performance on two operant timing schedules. Psychopharmacology 151:379-391

Fletcher PJ, Korth KM, Chambers JW (1999) Depletion of brain serotonin following intra-raphe injections of 5,7-dihydroxytryptamine 
does not alter $d$-amphetamine self-administration across different schedule and access condition. Psychopharmacology 146:185-193

Fuxe K, Ungetstedt U (1970) Histochemical, biochemical and functional studies on central monoamine neurons after acute and chronic amphetamine administration. In: Costa E, Garattini S (eds) Amphetamines and related compounds. Raven, New York

Gibbon J, Malapani C, Dale CL, Gallistel C (1997) Toward a neurobiology of temporal cognition: advances and challenges. Curr Opin Neurobiol 7:170-184

Harrison AA, Everitt BJ, Robbins TW (1997) Central 5-HT depletion enhances impulsive responding without affecting the accuracy of attentional performance: interactions with dopaminergic mechanisms. Psychopharmacology 133:329-342

Hinton SC, Meck WH (1997) How time flies: functional and neural mechanisms of interval timing. In: Bradshaw CM, Szabadi E (eds) Time and behaviour: psychological and neurobehavioural analyses. Elsevier, Amsterdam

Ho M-Y, Al-Zahrani SSA, Al-Ruwaitea ASA, Bradshaw CM, Szabadi E (1998) 5-Hydroxytryptamine and impulse control: prospects for a behavioural analysis. J Psychopharmacol 12:68-78

Ho MY, Velazquez-Martinez DN, Bradshaw CM, Szabadi E (2002) 5Hydroxytryptamine and interval timing behaviour. Pharmacol Biochem Behav 71:773-785

Ichikawa J, Ishii $\mathrm{H}$, Bonaccorsco S, Fowler WL, O'Laughlin IA, Meltzer HY (2001) 5-HT2A and D2 receptor blockade increases cortical DA release via 5-HT1A receptor activation: a possible mechanism of atypical antipsychotic-induced cortical dopamine release. J Neurochem 76:1521-153

Imai H, Steindler DA, Kitai ST (1986) The organization of divergent axonal projections of the midbrain raphe nuclei in the rat. J Comp Neurol 243:363-380

Killeen PR, Fetterman JG (1988) A behavioural theory of timing. Psychol Rev 95:274-295

Killeen PR, Fetterman JG, Bizo LA (1997) Time's causes. In: Bradshaw CM, Szabadi E (eds) Time and behaviour: psychological and neurobehavioural analyses. Elsevier, Amsterdam

Kucenski R, Segal DS (1989) Concomitant characterisation of behavioural and striatal neurotransmitter response to amphetamine using in vivo microdialysis. J Neurosci 9:2051-2065

Levant B, Grigoriadis DE, Desouza EB (1992) Characterization of $[3 \mathrm{H}]$ quinpirole binding to $\mathrm{D}_{2}$-like dopamine-receptors in rat brain. J Pharmacol Exp Ther 278:929-935

MacDonald CJ, Meck WH (2004) Differential effects of clozapine and haloperidol on interval timing in the supraseconds range. Psychopharmacology 182:232-244

Machado A, Guilhardi P (2000) Shifts in the psychometric function and their implications for models of timing. J Exp Anal Behav 74:25-54

Matell MS, Meck WH (2004) Cortico-striatal circuits and interval timing: coincidence detection of oscillatory processes. Cogn Brain Res 21:139-170

Meck WH (1986) Affinity for the dopamine $\mathrm{D}_{2}$ receptor predicts neuroleptic potency in decreasing the speed of an internal clock. Pharmacol Biochem Behav 25:1185-1189

Meck WH (1996) Neuropharmacology of timing and time perception. Cogn Brain Res 3:227-242

Meck WH (2006) Neuroanatomical localization of an internal clock: a functional link between mesolimbic, nigrostriatal, and mesocortical dopaminergic systems. Brain Res 1109:93-107

Meck WH, Benson AM (2002) Dissecting the brain's internal clock: how frontal-striatal circuitry keeps time and shifts attention. Brain Cogn 48:195-211

Millan MJ, Maiofiss L, Cussac D, Audinot V, Boutin JA (2002) Differential actions of antiparkinson agents at multiple classes of monoaminergic receptor. I. A multivariate analysis of binding profiles of 14 drugs at 21 native and cloned human receptor subtypes. J Pharmacol Exp Ther 303:791-804

Moreland RB, Nakane M, Donnelly-Roberts DL, Miller LN, Chang RJ, Uchic ME, Terranova MA, Gubbins EJ, Helfrich RJ, Namovic MT, El-Kouhen OF, Masters JN, Brioni JD (2004) Comparative pharmacology of human dopamine $\mathrm{D}_{2}$-like receptor stable cell lines coupled to calcium flux through $\mathrm{G} \alpha_{\mathrm{qo} 5}$. Biochem Pharmacol 68:761-772

Moser PC, Moran PM, Frank RA, Kehne JH (1996) Reversal of amphetamine-induced behaviours by MDL 100,907, a selective 5- $\mathrm{HT}_{2 \mathrm{~A}}$ antagonist. Behav Brain Res 73:163-167

Odum AL, Lieving LM, Schaal DW (2002) Effects of $d$-amphetamine in a temporal discrimination procedure: selective changes in timing or rate dependency. J Exp Anal Behav 78:195-214

O'Neill MF, Heron-Maxwell CL, Shaw G (1999) 5-HT 2 receptor antagonism reduces hyperactivity induced by amphetamine, cocaine and MK-801 but not $\mathrm{D}_{1}$ agonist C-APB. Pharmacol Biochem Behav 63:237-243

Paxinos G, Watson C (1998) The rat brain in stereotaxic coordinates, 2nd edn. Academic, New York

Pehek EA, McFarlane HG, Magaschak K, Price B, Pluto CP (2001) M100,907, a selective 5-HT2A antagonist, attenuates dopamine release in the rat medial prefrontal cortex. Brain Res 888:51-59

Rothman RB, Baumann MH, Dersch CM, Romero DV, Rice KC, Carroll FI, Partilla JS (2001) Amphetamine-type central nervous system stimulants release norepinephrine more potently than they release dopamine and serotonin. Synapse 36:32-41

Seeman P, Van Tol HHM (1994) Dopamine receptor pharmacology. Trends Pharmacol Sci 15:264-270

Seiden LS, Sabol KE (1993) Amphetamine: effects on catecholamine systems and behaviour. Annu Rev Pharmacol Toxicol 32:639677

Sershen H, Hashim A, Lajtha A (2000) Serotonin-mediated dopamine release involves the dopamine uptake site and the serotonin receptor. Brain Res Bull 53:353-357

Sokoloff P, Giros B, Martres MP, Bouthenet ML, Schwartz JC (1990) Molecular cloning and characterization of a novel dopamine receptor $\left(\mathrm{D}_{3}\right)$ as a target for neuroleptics. Nature 347:146-151

Sorenson SM, Kehne JH, Fadayel GM, Humpherys TM, Ketteler HJ, Sullivan CK, Taylor VL, Schmidt CJ (1993) Characterisation of the 5- $\mathrm{HT}_{2}$ receptor antagonist MDL 100907 as a putative atypical antipsychotic: behavioural, electrophysiological and neurochemical studies. J Pharmacol Exp Ther 266:684-691

Stubbs DA (1976) Scaling of stimulus durations by pigeons. J Exp Anal Behav 26:15-25

Stubbs DA (1980) Temporal discrimination and a free-operant psychophysical procedure. J Exp Anal Behav 33:167-185

Tang L, Todd RL, Heller A, O’Malley KL (1994) Pharmacological functional characterization of $\mathrm{D}_{2}, \mathrm{D}_{3}$ and $\mathrm{D}_{4}$ dopamine receptors in fibroblast and dopaminergic cell lines. J Pharmacol Exp Ther 268:495-502

Van Tol HHM, Bunzow JR, Guan HC, Sunahara RK, Seeman P, Niznik NB, Olivier C (1991) Cloning of the gene for a human dopamine $\mathrm{D}_{4}$ receptor with high affinity for the antipsychotic clozapine. Nature 350:610-614

Wogar MA, Bradshaw CM, Szabadi E (1992) Impaired acquisition of temporal differentiation performance following lesions of ascending 5-hydroxytryptaminergic pathways. Psychopharmacology 107:373-378

Winstanley CA, Dalley JW, Theobald DEH, Robbins TW (2003) Global 5-HT depletion attenuates the ability of amphetamine to decrease impulsive choice on a delay-discounting task in rats. Psychopharmacology 170:320-331 